\title{
The Paradox of Juluk Adek Adat Pepadun Megou Pak Tulangbawang Ritual Related to Restructuring Social Environtment
}

\author{
Tri Wahyuni ${ }^{1}$, Nurhayati Nurhayati \\ Department of Linguistics, Faculty of Humanities, Diponegoro University, Semarang - Indonesia
}

\begin{abstract}
This article discusses the paradox in the juluk adek 'giving customary/ adat title' ceremony of the adat Pepadun Megou Pak Tulangbawang, Lampung. This descriptive qualitative research in the scope of ethnography of communication uses primary data in the form of communication patterns in the juluk adek ceremony conducted by $b i$ kelamou 'wife of groom's uncle', which seen by punyimbang 'the leader of adat', peghwatin 'adat's actor', and the bride-groom's family. The author uses the distance elicitation method with virtual interview techniques, records, and notes. There were 13 lexicons in the form of verbal spoken by kelamou which have the meaning changing adjusted to the current social conditions of society. In addition, there were also 7 lexicons that should not be used and carried out in the procession of the juluk adek ceremony because they were considered to be sengok 'bad consequences'. If these things were violated, the consequence was that the bride-groom's family must pay the dau 'adat fines' decided in the pepung 'adat meeting' in the sesat agung 'traditional hall' of Lampung Pepadun Megou Pak Tulangbawang, Lampung. Although many rituals must be undertaken, in the current social and pandemic conditions the procession is still carried out with some adjustments.
\end{abstract}

Keywords: paradox, juluk adek ceremony, Pepadun Megou Pak Tulangbawang, ethnography of communication

\section{Introduction}

Research on ethnography of communication cannot be separated from people's lives. Every culture has its own uniqueness and regularity in communication patterns. Ethnography of communication makes language a cultural existence in the main social situation. However, according to Saville-Troike, quoted by Ibrahim [1] one needs to analyze the codes contained in the culture of society with the cognitive process of the speaker and the listener. Ethnography of communication is the field of ethnolinguistics or sociolinguistics about language in relation to all variables outside of language [2]. The science is derived from

${ }^{1}$ Corresponding author: twahyuni99@gmail.com 
anthropology which has a relationship with the field of sociology. The study of ethnography of communication analyzes the phenomenon of socio-cultural interaction in society, the role in social systems, and so on [3]. In Indonesia, society consists of various ethnic groups and unique cultures. Cultural diversity arises due to differences in interpretation of cultural elements [4]. Cultural diversity in society can be in the form of various types to describe the unique side of a community group. According to Gerard Hendrik Hofstede, Dutch social psychologist, as quoted by Zakiah [5] there are four things or concepts that encompass a variety of cultural episodes, namely symbols, heroism, ritual activities, and values. There are many things that are within the scope of culture that exists in the rituals of a cultural community. Among them are things that are sacred, words that should not be said or done, offerings to ancestors, spells, and so forth.

Processions and rituals characterize the human life cycle in a group. Various cultural activities are supported by the existence of various kinds of indigenous peoples who have various kinship laws and forms of customs [6]. The Lampung community consists of two big jurai or 'adat', the Saibatin jurai and the Pepadun jurai. However, there are also those who interpret the jurai as a group. The motto "Lampung Sang Bumi Ghuwa Jurai" is interpreted as Lampung, the earth of two groups, namely indigenous groups and migrant groups. This paper presents the paradox that exists in the procession of Juluk Adek in the form of verbal and non-verbal lexicon that is limited to the Pepadun tradition, specifically Megou Pak Tegamo'an 'which is located in Penumangan Lama Village, Central Tulangbawang, Tulangbawang Barat District, Lampung Province.

The philosophy of the people of Lampung in the two jurai is Piil Pesengiri which consists of pesengiri, juluk adek, nengah nyappugh, sakai sambayan. This philosophy is held firmly as the identity of the Lampung indigenous people with the translation of the pesengiri is a philosophy that shows that the people of Lampung have a price that is paid at a fixed price. All the clans in Lampung feel they have high dignity and dignity as members of indigenous peoples who have noble wisdom values that were purified from previous kings with the book of Kuntara Raja Niti. The philosophy of juluk adek is something that must be owned by the people of Lampung. People who have a traditional title certainly have their own prestige in indigenous communities. The people of Lampung really value older people, who are more knowledgeable, and have a position, both in government and in society. The juluk adek is a necessity by the people of Lampung to maintain customary culture in their culture. The middle-aged philosophy shows the attitude of the people of Lampung that is easy to blend in with the community. Being in the midst of indigenous peoples and mixed with all layers. This is a characteristic that can be seen in everyday life when they can adapt to the immigrant community. The philosophy of sakai sambayan shows that the characteristics of Lampung people are mutual cooperation in all lines of life. Life of helping one another is very much in harmony with customary and religious norms prevailing in Lampung society.

In cultural rituals the role of language is very large. The use of certain lexicons that are routine and frozen are certainly one of the characteristics. Most of the people of Lampung embraced Islam, so that the adat or customary processions that exist in the two jurai also uses Islam rules. On the one hand, Islam is influenced by a particular culture or culture (in this case Lampung culture), on the other hand a culture enriched with treasures of Islamic knowledge [7]. At present, technological advances also affect the way people look at carrying out cultural and traditional rituals. There are several lexicons that are considered to be no longer relevant to the current social conditions of society. Therefore, there are some adjustments to traditional rituals with the current social conditions. This paper discusses the paradox in the juluk adek ceremony at the adat of Pepadun traditional marriage procession. Associated with culture, marriage ceremonies in Indonesia are universally understood events, although the procedures for implementing them differ [4]. There have been many writings that discuss Piil Pesengiri's philosophy from several aspects. Ahmad Isnaeni and Kiki 
Muhammad Hakiki wrote about "Symbols of Islam and Custom in Lampung Pepadun Marriage" in 2016 in the Kalam journal [8]. Fathu Sururi who discussed "Mak di Juk Siang on Lampung Indigenous Peoples Pepadun Megou Pak" in 2016 in the Al Hukama journal [9]. The two writings discussed the implementation of Piil Pesengiri in Lampung Pepadun adat from the perspective of Islamic religion, namely the prohibition of divorce and Islamic symbols used in traditional ceremonies. Coinciding with the shift in the community's perspective on the ritual procession in the current social conditions, Obing Katubi [10] in his study "Lampungic Languages: Looking for New Evidence of the Possibility of Language Shift in Lampung and The Question of Its Revers" also once described a shift language that can affect the way of Lampung society's view of culture. Jeffrey B. Kingston [11] specifically revealed the manipulation of adat that had taken place in Lampung during colonialism. From some of the writings, as far as the author's knowledge there is no writing that specializes in the paradox that exists at the juluk adek ceremony in the Pepadun traditional wedding procession, especially Megou Pak Tulangbawang, in West Tulangbawang Regency, Lampung Province. Therefore, the authors are interested in examining this matter in this article.

This research is focused on the assumptions or paradoxes in the form of lexicons that should not be spoken and carried out by the bride and groom. If it is violated, then they believe the bride and groom's family will meet tulah 'difficulties or plagues' in their domestic life. Besides verbal utterances, the taboo lexicons are also expressed in non-verbal forms, such as clearing their throat, opening betel boxes, cloth colors used as candang warang 'the white cloth sorrounding the field of Lampung's traditional ceremony', and stepping on buffalo heads. This study seeks to describe how the paradox that exists at the juluk adek ceremony in Lampung Pepadun Megou Pak Tulangbawang traditional wedding processions and how to adjust to the current social conditions. So that information will be presented about the types of paradoxes and their application in social conditions that have changed.

\section{Research Method}

This article is a qualitative descriptive study. This article uses the distance elicitation method with interview techniques [12]. The method is used because of the current pandemic conditions that force us not to make intensive contact. Therefore, researchers utilize social media in this article. The method is breaking into data acquisition methods and methods of analysis and presentation.

\subsection{Data Acquisition Method}

Data obtained by virtual interviews with participants in the juluk adek ceremony in Lampung Pepadun Megou Pak Tulang Bawang traditional marriage procession. The author involved several respondents to be interviewed by means of listening, engaging, competent, and recording conducted online in the middle of a covid-19 pandemic situation. The author determines the criteria of respondents with general research objectives so that the spirit of research continues to emerge and can be discussed. In addition, the author also triangulated to check the validity of the data by cross-checking with a number of local adat (punyimbang and peghwatin) stakeholders (interviews via mobile phone). Meanwhile, the interviewees consisted of participants in the juluk adek ceremony, namely the punyimbang 'adat's leader', peghwatin 'adat's actor', bi kelamou 'wife of groom's uncle', meghiyan majeu 'bridegroom', ulun tohou pesabai 'the bride-groom's parents', at the wedding ceremony of Putra Sanjaya and Mira located in tiyuh 'village' Penumangan Lama, Tulangbawang Tengah, 
Tulangbawang Barat District, Lampung. The participants were interviewed using the telephone line and the Whatsapp application and the video of juluk adek on the Putra Sanjaya' Facebook account. Eight informants from the research field (located in Penumangan Lama Village) were chosen as a core in that event to be interviewed. The demographic information of the eight informants is reported in table 1. 
Table 1. Demographic Information of Informants

\begin{tabular}{|c|c|c|c|}
\hline No & Name of informant & Age & Role \\
\hline 1. & $\begin{array}{l}\text { Badaruddin Yusuf gelar Stan Rajou } \\
\text { Jaya }\end{array}$ & 58 & $\begin{array}{l}\text { Punyimbang 'the leader } \\
\text { of adat' }\end{array}$ \\
\hline 2. & $\begin{array}{l}\text { Sulisman Arsyad gelar Stan Dalem } \\
\text { Sampurna }\end{array}$ & 57 & peghwatin 'adat's actor' \\
\hline 3. & Lison gelar Tuan Sembah Agung & 53 & peghwatin 'adat's actor' \\
\hline 4. & $\begin{array}{l}\text { Amirson gelar Ngedekou Pimpinan } \\
\text { Minak Pujian }\end{array}$ & 56 & peghwatin 'adat's actor' \\
\hline 5 . & Autina gelar Minak Pujian & 48 & $\begin{array}{l}\text { bi kelamou 'wife of } \\
\text { groom's uncle' }\end{array}$ \\
\hline 6. & Putra Sanjaya gelar Pengiran Sejati & 23 & meghiyan 'groom' \\
\hline 7. & Mira gelar Minak Sejati & 20 & majeu 'bride' \\
\hline 8. & $\begin{array}{l}\text { Ibrahim Senor gelar Pengiran } \\
\text { Waybalak }\end{array}$ & 65 & $\begin{array}{l}\text { ulun tohou pesabai 'the } \\
\text { bride-groom's parents' }\end{array}$ \\
\hline
\end{tabular}

\subsection{Analysis and Presentation Methods}

The data obtained were analyzed using the ethnolinguistic approach. This was done so that in this study obtained communication patterns that are intertwined in the juluk adek ceremony in the Lampung Pepadun traditional marriage procession in West Tulangbawang Regency, Lampung. Data is presented formally and informally by looking at the symptoms that appear in the communication patterns of the ritual. A formal presentation is in the form of a list of lexicons that are forbidden to pronounce by kelamou and its alternative lexicon in the juluk adek ceremony. Informal data in the form of a comprehensive description of the data studied, namely patterns of communication between participants involved in the juluk adek ceremony.

\section{Results and Discussion}

The unit of analysis or research setting of ethnography of communication in the juluk adek ceremony is the indigenous people of Pepadun Megou Pak, precisely in the village of Penumangan Lama, Central Tulangbawang Tengah, Tulangbawang Barat District, Lampung. In general, pepadun indigenous people are scattered in several regions of Lampung, especially people who live in rural areas [13]. The language used is Lampung Nyow (O) dialect. In the area of Tulangbawang Barat Regency (division of Tulangbawang Regency) there are at least four clans, one of which is the megou pak (clan four) of Tulangbawang. The setting of this study is focused on the Tegamo'an clan living in the Penumangan Lama and Pagardewa areas.

The event that will be examined is the marriage ceremony procession which is also called begawi adat (a marriage procession consisting of several sub-events which is a series of ceremonies that must be passed in the tradition of pepadun, especially with the application system $\left(j u j u r^{2}\right)$, not larian ${ }^{3}$ ). The sub-events in the begawi adat procession are divided into

\footnotetext{
2 The marriage system in Lampung with several legal ritual

${ }^{3}$ The marriage system in Lampung where the groom takes the bride out from her parent's home and leave a several money and letter
} 
three parts, namely before the marriage contract, when the marriage contract, and after the marriage contract. The third series of events is carried out in a row by holding a pepung adat 'traditional meeting' in the sesat agung 'Lampung traditional house', pepung muli meghanai 'boys-girls's meeting', jaga damar 'staying up all night long', nyubuk 'looking in secretly ', and nyuwak' invite guests'.

\subsection{The Communication Act in the Juluk Adek Ceremony}

In the procession, which was authorized by adat was bi kelamou 'wife of groom's uncle'. After the posokan 'bribing' event, bi kelamou wears complete Lampung traditional clothes such as tapis 'Lampung traditional cloths made from golden yarn weaving', sulam usus 'band chrochet style' kebaya, and siger 'traditional crown'. In addition, kelamou must hold the key as a symbol of giving a traditional adat title. The bride and groom were paraded towards the pacah haji pepadun 'the throne of pepadun' in the form of a high chair wrapped in white cloth. The place where the juluk adek held was surrounded by a candang warang 'white cloth that surrounds the ceremony arena'. The participants' focus on the juluk adek ceremony in the Lampung Pepadun traditional marriage procession was the bride and groom, the parents of the bride-groom, and the traditional leaders of Pepadun.

$\begin{array}{ll}\text { Meghiyan: groom } & \rightarrow \mathrm{X} 1 \\ \text { Majeu: bride } & \rightarrow \mathrm{X} 2 \\ \text { Punyimbang: adat leader } & \rightarrow \mathrm{X} 3 \\ \text { Peghwatin: adat actor } & \rightarrow \mathrm{X} 4 \\ \text { Ulun tohou pesabai: the parents of the bride and groom } & \rightarrow \mathrm{X} 5 \\ \text { Bi Kelamou: wife of groom's uncle } & \rightarrow \mathrm{X} 6\end{array}$

Communication patterns that occur in the procession begins with a pepadun cangget 'traditional dance' performance, which is a dance to welcome the great guests in the tradition of pepadun, which is danced by five Lampung girls. There are several lexicons that are considered paradoxical by the people in the juluk adek, both verbal and non-verbal. 


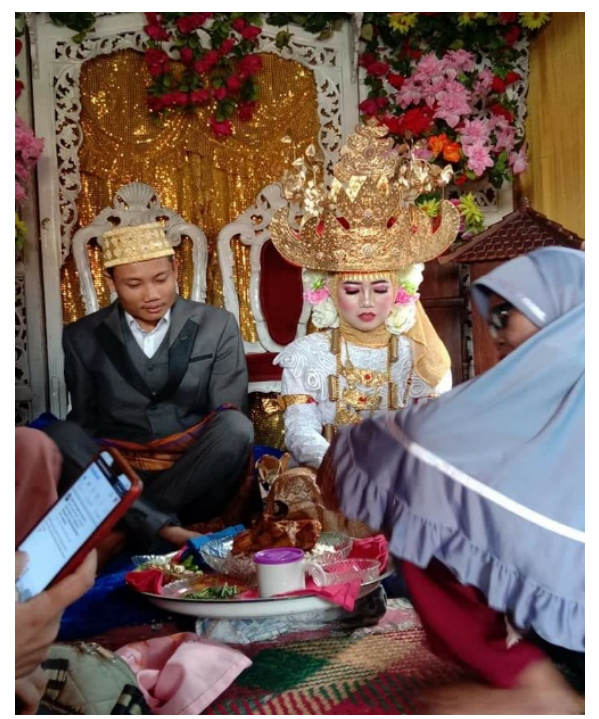

Fig. 1. The Juluk Adek of Meghiyan Majeu ceremony by Bi Kelamou during the marriage procession of Putra Sanjaya and Mira in adat of Pepadun Megou Pak Tegamo'an held in Tulangbawang Barat

Regency at 19 April 2020 (Source: Personal documentation)

The procession of juluk adek as shown in the figure was done during thecovid-19 pandemic conditions. So many things that were not done by the participants in the midst of limitations due to the government's recommendation to be obeyed, which is prohibited from holding meetings that involve many people. So, the procession of juluk adek discussed in this article was only attended by a number of core participants and a limited number of guests. In the procession, it was also seen that bi kelamou did not make any special requirements for kelamou to wear complete custom clothing. This certainly caused the consequences of dau 'adat's fines' after the event.

The juluk adek procession done by bi kelamou has a frozen lexicon in the form of the words sai, wou, tegou, pak, lemou, nem, piteu ... 'one, two, three, four, five, six, seven ...' which must not be replaced by words another when they want to give a traditional title while holding the key that is stuck on the forehead of the bride-groom in turns. The meaning of the seven numbers is called symbolizing the purpose of life, meanwhile, the key symbolizes the key to open the bride-groom's way of life to face the household. The key that is placed on the bride-groom's forehead is intended so that the message of the parent enters the bride-groom's mind, the bride-groom's mind which is initially closed becomes open with the key.

Cultural symbols in the juluk adek process contain deep meaning in the form of advice for the bride and groom. In the current social conditions, many things are no longer in accordance with the history of the procession of the juluk adek in the Lampung adat community, in particular. However, the

essence in the procession in the form of awarding titles containing certain meanings is still maintained. Changes in the condition of society in the fields of education, mobility, economy, and information affect socio-cultural changes, especially in the rituals that lend the lexicon in use. 


\subsection{The paradox in the Ceremony of the Juluk Adek (Verbal Lexicon)}

\section{Communication Act}

X3 : Bismillah, tabik pun ngalimpugha. Putra Sanjaya, niku wou bi meu jou tanou kak agou mesou juluk adek pun. Kayin andak sulam setegho, ki temen niku wou sayang di gham, pusau pai pudak jamou dadou. Dang sappai wat penyakik jak ulun sai sangun makai kawai apui. Agow kedey niku?

$\mathrm{X} 1$ : Ya, puun Penyimbang sai dikayun peppung adat, ikam wou bi agou.

X3 : Payeu kidah. Nyak ngitaaghken niku wou lapah unut pai jamoumu sai ghamik, dang lopou kenou tulah sai dicawou ghagah-ghagah. Tabik pun tabik ngalimpura, bi Putra...temen sai temen kedey niku agou nutuk segalou caghou adat di jes ejou? Dang bou bou penyakik jak luah, katteu kenou tulah. Bou pai badan waghas, slamat, panjang omogh

X2 : ya puun, ikam agou nutuk segalou caghou adat dijou, nutuk meghiyan ikam.

ya, saya bersedia mengikuti semua adat dan cara di sini dan mengikuti suami saya.

X3 : Payeu kidah...injung-injung kayin sinjang, kipak salah di pinjungkeu, kenawat bagho dipudakkeu, puun....selamet, panjang omogh, waghas segalou puun. Wat ughik nayah lemaweng, nayah keghou, babuy goh di pelan ...tabik tabik pun tabik, kiluy jawoh.
Transliteration

X3 : 'Bismillah, excuse me, sorry. Putra Sanjaya, you and your wife will now receive the title. White cloth embroidered with silk, if indeed you love us don't forget to wipe your face and chest. There must be no disease from people in fireworks. Provide you, guys?'

X1 : 'Yes, Punyimbang 'adat leader' sent

by pepung 'adat meeting, we are willing.

X3 :'Alright, I walk you guys, then follow your many friends. Don't forget and be careful of the tulah 'plagues' that men say. Excuse me, I'm sorry, Putra's wife, are you really willing to follow all the adat methods that are here? Don't bring disease from outside, you will get tulah 'plagues. Bring a healthy body, safe, and long life'.

X2 :'Yes, I am willing to follow all the customs and methods here and follow my husband'.

X3 : 'Alright, the sarong is clothed, even though it's wrong on my sarong, the full moon is on my face. Good luck, long life, all healthy. There are lives of many tigers, lots of monkeys, pigs like in the forest ... tabik pun even ask to be kept away'.

\section{Musuh 'enemy'/ belis 'devil' $\rightarrow$ penyakik 'disease'}

From the communication pattern that exists between the punyimbang and the bride-groom confirms the message for the lives of the bride-groom face the household. The lexicon printed in yellow penyakik 'disease' is an alternative lexicon of the musuh 'enemy' or belis 'devil' - which is considered not good - which is said by punyimbang and peghwatin because it contains advice. The punyimbang accompanied by peghwatin asked the bride and groom about their readiness to foster households and obey adat's rules. The punyimbang and the peghwatin sit cross-legged in front of the bride and groom who will prepare to receive the title in a series of juluk adek ceremonies that are preceded by the position of posokan 'bribery'. 
The punyimbang and peghwatin alternately mosok 'feed the bride and groom' with buffalo meat, rice, and drinking water accompanied by the sound of canang beats and the euphoria of the audience. The rice used for the supply is white rice with the kalat 'side dish' buffalo meat cooked with spices, it should not be spicy with a complement of boiled chicken eggs and drinking water. The equipment is strived for all without artificial colors, truly original. It contains symbolic meaning that the "initial capital" of the bride and groom are pure and clean things.

The procession was also carried out with the hands of a pemosok 'briber' scourer who had previously prepared a kobok 'water in a container to wash hands before mosok'. Communication acts between the punyimbang and the bride-groom contain a lexicon that refers to things that are considered to bring disaster. In their belief, calling the musuh 'enemy' or belis 'devil' is replaced by a lexicon of penyakik 'disease' so that unexpected things do not happen. There is an unwritten vengeful hatred of certain tribes which should not be mentioned in all traditional rituals.

The tribe mentioned is replaced by the lexicon ulun sai makai kawai apui 'the person who wears fire clothing'. The lexicon of penyakik and ulun sai makai kawai apui is a form of symbolic interactionism that refers to certain referents that are considered taboo. The lexicon of tulah 'plagues' and tabik 'regards e.g. excuse me' is also full of meaning that refers to the taboo lexicon, instead of God forbid, hopefully no undesirable things will happen.

In addition to the communication patterns that exist between the punyimbang,and peghwatin, the main event in the juluk adek is the communication conducted by kelamou, ulun tohou pesabai, and the bride-groom. The following is a pattern of communication that occurs and contains several taboo lexicons. Kelamou asked the bride and groom about their readiness to receive the title in a series of juluk adek ceremonies that were preceded by posokan 'bribing' (the process was the same as that of the punyimbang and peghwatin) 
Pola Komunikasi

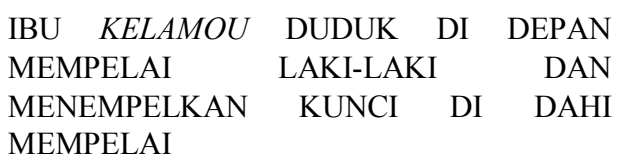

X6 :'Bismillah, tabik pun ngalimpugha. Putra Sanjaya jamou Mira, niku wou bi lakei kak agou mesou juluk adek pun. Hak tawagh, bisou tawagh, layin nyak sai ngeguai taawagh, Allah pus ai nawaghei. Wat kayeu pakai nuwou, wat kayin pakai sinjang, nyou maksud enow, Putra?

X1 : Ughik gham mesou bangik cukup segalou galou.

'hidup kami akan bahagia.

X6 : Ya, puun, sai, wou, tegou, pak, lemou, nem, piteu...adekmou jow pak pengighan, cuwak adimeu kak ighan, cuwak nakenmeu apak pengighan....kiluy selamat, waghas, panjang omogh. (soghaakk, eeey)

\section{IBU KELAMOU BERPINDAH PADA MEMPELAI WANITA DAN MENEMPELKAN KUNCI DI DAHI MEMPELAI...}

X6 : Sai, wou, tegou, pak, lemou, nem, piteu...adekmou jow minak sejati, cuwak adimeu sejati, cuwak nakenmeu ibeu sejati....kiluy selamat, waghas, panjang omogh. (soghaakk, eeey)

X2 : ya puun, ikam agou nutuk segalou caghou adat dijou, nutuk meghiyan ikam.

ya, saya bersedia mengikuti semua adat dan cara di sini dan mengikuti suami saya.

X3 : Payeu kidah...injung-injung kayin sinjang, kipak salah di pinjungkeu, kenawat bagho dipudakkeu, puun...selamet, panjang omogh, waghas segalou puun. Wat ughik nayah lemaweng, nayah keghou, babuy goh di pelan...tabik tabik pun tabik, kiluy jawoh.
Transliteration

KELAMOU SITS IN FRONT OF THE GROOM AND PICK THE KEY UP ON HIS FOREHEAD

X6 : 'Bismillah, excuse me, sorry. Putra Sanjaya and Mira, you will now receive the title. Danger does not work, poison does not work, it is not I who do not work, it is God who enables. There is wood for the house, there is cloth for the sarong, what do you mean, Putra?'

X1 : 'our life will be happy'.

X6 :' Alright, one, two, three, four, five, six, seven ... your current title is $P a k$ Pengiran, a call to your brother and sister Kak iran, your nephew is calling apak Pengiran ... ask for good luck, long life, always healthy. (shrieked of audience)

KELAMOU IS MOVING ON THE BRIDE SIDE AND PICK THE KEY UP ON HER FOREHEAD

X6 :' Alright, one, two, three, four, five, six, seven ... your current title is minak sejati, a call to your brother and sister sejati, your nephew is calling $i b u$ sejati ... ask for good luck, long life, always healthy (shrieked of audience)

X2 : 'Yes, I am willing to follow all the customs and methods here and follow my husband.'

X3 : 'Alright, the sarong is clothed, even though it's wrong on my sarong, the full moon is on my face. Good luck, long life, all healthy. There are lives of many tigers, lots of monkeys, pigs in the forest ...tabik pun even ask to be kept away'. 


\section{Anak teladung 'lots of kids' $\rightarrow$ anak sai cukup, salih, saliha 'enough and obedient kids'}

Kelamou may not say kekalau niku wou ngemik anak teladung 'hopefully, you both have many children' to the bride-groom that they are begging for exemplary children. This is considered taboo because many children do not necessarily guarantee the bride-groom's life will be better. It is avoided because when having many children, they are unable to take responsibility.

Therefore, kelamou say kekalau nikeu wou ngemik anak sai cukup, salih saliha 'hopefully you both have an enough and obedient child'. This pattern of communication implies a fairly Islamic characteristic. The changing of this lexicon is such a suggestion. They believe that what they said will be a pray, so they have to be selective and careful use the diction in this ritual.

\section{Dang tudau 'don't be flirt' $\rightarrow$ jadei ulun sai wawai 'being a good person'}

Kelamou cannot say the message dang tudau nikeu 'you don't be flirt' because it is considered praying for the bride to be a bitch. The lexicon was replaced by jadei ulun sai wawai 'be a good person'. The alternative lexicon is chosen as the way to educate the people to use the better thing in their life. As declared before, the lexicon in the sacral ritual must be selective and adjust the good pray for better life.

\section{Mengan uyah isem 'eat acid and salt' $\rightarrow$ nayah pengalaman 'have a lot of experiences'}

Kelamou may not say the message kekalau ughikmu na'an mengan uyah isem 'hopefully your next life will eat salt and acid'. The lexicon is replaced by kekalau ughikmu na' an nayah pengalaman 'may your life be filled with lots of experience later'. Uyah 'salt' and isem 'acid' have a unique flavour. The clause mengan uyah isem means an experience, so that kelamou must changing and restructuring that lexicon in order to be a better pray for bride-groom household.

\section{Kayin kapan 'shroud' $\rightarrow$ kaci 'white cloth'}

Kelamou may not say the message wat kayin kapan di dighei 'there is a shroud in you' because its considered praying for the bride-groom's relationship not to last. The shroud symbolizes death. The lexicon was replaced by wat kaci di dighei 'there is clean white cloth in you'. The alternative lexicon symbolizes cleanliness in marriage life, both psychally and spiritually.

\section{Dang lawang 'don't crazy' $\rightarrow$ waghas, slamat 'safe and healthy'}

Kelamou may not say the message dang lawang niku 'don't crazy you' because it is considered praying for the bride-groom to behave in violation of adat norms and rules. The lexicon is replaced by kekalau nikeu waghas, slamat 'hopefully you will safe and healthy'. The alternative lexicon has a prayer of hope in order to happy and prosperous.

\section{Saghou 'miserable' $\rightarrow$ ughik bangek 'have a good life'}


Kelamou must not say the message ughik saghou 'miserable life' because it is considered praying for the bride-groom to live in poverty or miserable. The lexicon is replaced by kekalau ughikmu bangek 'may your life always be happy'. This lexicon is chosen as a good suggestion and pray for bride-groom's life in the community.

\section{Matei 'die' $\rightarrow$ panjang omogh 'long life'}

Kelamou cannot say the message matei 'die' because it is considered hopeless and loss of life destination. The lexicon was replaced with panjang omogh 'long-life'. The alternative lexicon has a prayer of hope in order to happy, prosperous, and have a long-lasting relationship in marriage.

\section{Tadai agou 'lots of demans' $\rightarrow$ kana'ah, ngegasou cukup di mengan nginem 'feel enough for eat and drink'}

Kelamou must not say the message dang nayah tadai agou 'don't have a lot of demands' because it is considered praying for the bride-groom to be extravagant and wasteful. The lexicon is replaced with kana'ah, ngegasou cukup di mengan nginem 'always feeling enough with what is gained'. This lexicon has an advice in order to the bride-groom will live simply and fulfill their need well.

\section{Jejugil 'poke' $\rightarrow$ jagou kayeu aghou 'take care of adat tree'}

Kelamou may not say the message dang jejugil nikeu 'don't poke anybody' because it is considered praying for the bride-groom to be unfaithful and tends to cheat. The lexicon was replaced by jagou kayeu aghou 'take care of kayeu aghou or family honor'. This alternative lexicon describes a form a cultural preservation and an effort to maintain the honor of household.

\section{Payah badan 'tired' $\rightarrow$ badan waghas 'healthy'}

Kelamou must not say the message dang payah badan 'don't get tired' because it is considered praying for the bride-groom to be lazy. The lexicon is replaced by kekalau badan metei waghas 'hopefully you both always healthy'. It describes that the community has a good hope for next generation. 


\section{Dang selagou 'don't have a figt each other' $\rightarrow$ rukun, sayang jamou bi jamou anak-anak 'get along well, have an affection to kids'}

Kelamou may not say the message dang selagou 'don't fight' because it is considered praying for the bride-groom to be selfish at all. The lexicon was replaced with rukun pai, sayang jamo bi jamou anak-anak 'get along well, have an affection to the wife and children'.

\section{Naghat / melap 'vanished' $\rightarrow$ ngemik dau, cukup di ughik 'there is wealth, enough in life'}

Kelamou may not say the message nagha / wipe 'lost or destroyed' because it is considered praying for the bride lost direction. The lexicon was replaced with ngemik dau, cukup di ughik 'living well with owning dau or wealth in life'.

\subsection{The paradox in the Ceremony of the Juluk Adek (Non-Verbal Lexicon)}

\section{Kawai agheng 'black outfit'}

In the procession juluk adek was not allowed to wear black clothes which was a symbol of mourning. The community believe if there is a participant who wears the black outfit in this procession, it can be the symbol that the bride-groom will face the miserable.

\section{Kawai bughak 'bad clothes'}

What is meant by bad clothes are ordinary clothes, not the traditional clothes agreed in the pepung 'adat meeting'. In the figure before kelamou wear ordinary clothes, not traditional clothes, so the consequence, after the event ends, the family must pay dau at sessat agung 'Lampung adat hall'.

\section{Kayin agheng 'black cloth'}

Black cloth is not allowed to be used as a candang waghang because it symbolizes grief.

\section{Jandou / dudou 'widow or widower'}

If in the bride-groom's family there are brothers or sisters who are widowed or widower, they may not attend the juluk adek ceremony because it is considered not good. The widow or two in the family must be "hidden" in the bridal chamber by holding a knife and saying nyak lemaweng, niku nou manok lunik "I am a tiger, you are little chicken". The purpose of these words is that the widow or widower is still respected by the new family.

\section{Tukegh mengan 'bribe coins with the bride's mouth'}

Bribery of coins between bride and groom is not permitted. The most entitled participant is the mother of the groom to the bride. 


\section{Tetang sabik}

Tetang sabik can only be done after seven days of the marriage procession, not during the juluk adek ceremony. This is considered sacred and very intimate, so it should not be reported to those guests in that event.

\section{Sasou salah 'name of plants'}

Sasou salah is a type of leaves in the Lampung forest. In the procession juluk adek may not have that types of flora, because it used in another ritual after marriage contract. The adat deciding to ban this flora because they believe it is considered the praying for the bridegroom will always false and have a miserable life. However, now sasou salah leaf are rarely, so it is not a problem anymore. One of the aims of this ban in order to keep the forest sustainable.

After giving a traditional title or juluk adek which is done by the bi kelamou, the bridegroom have any legitimacy to be called by their adat title or juluk and adek. The title is officially used in every Lampung pepadun traditional event which is followed after marriage. The cuwakan 'adat nickname' that were pinned to the bride and groom began to be officially practiced for their younger siblings and nieces. Summon from parents after marriage also exists, but it is not specified in the ceremony, it is internal. For example, Putra Sanjaya's wife after being officially married, her parents-in-law will call by special nicknames that are determined internally, for example Rugayah or names that they respect.

\section{Conclusion}

\subsection{Conclusion}

From the study conducted at the juluk adek ceremony which is full of the nuances of Islam, there are 13 lexicons which are paradoxical in the ceremonial procession in the adat Pepadun Megou Pak Tulangbawang, namely (1) musuh or belis was replaced by penyakik, (2) anak teladung was replaced by ngemik anak sai cukup, salih saliha, (3) dang tudau was replaced by jadei ulun sai wawai, (4) mengan uyah isem was replaced by nayah pengalaman, (5) kayin kapan was replaced by kaci, (6) dang lawang was replaced by waghas, slamat, (7) saghou was replaced by ughik bangek, (8) matei was replaced by panjang omogh, (9) tadai agou was replaced by kana'ah, ngegasou cukup di mengan nginem, (10) jejugil was replaced by jagou kayeu aghou, (11) payah badan was replaced by waghas, slamat (12) dang selagou was replaced by rukun, sayang jamou bi jamou anak-anak, (13) naghat/melap was replaced by ngemik dau, cukup di ughik.

The 13 taboo lexicons were carried out by kelamou who had the authority to give adat titles to the bride and groom witnessed by the other participants, namely meghiyan, mejeu, punyimbang, peghwatin, and ulun tohou pesabai. Those 13 alternative lexicons are the way of community in Adat Pepapun Megou Pak Tegamo'an restructuring the mindset of people in other to have a better life by using the good lexicon. In addition to the 13 taboo lexicons which are verbal, there are also non-verbal taboo lexicons in the form of equipment that should not be used or things that should not be done during the procession. There are 7 nonverbal taboo lexicons, namely (1) kawai agheng, 2) kawai bughak, (3) kayin agheng, (4) jandou / dudou, (5) tukegh mengan, (6) tetang sabik, and (7) sasou salah. The procession of the juluk adek ceremony has changed amidst the changing social conditions. The existence 
of verbal and non-verbal lexicons is a reflection of the regional cultural wealth within the scope of national cultural diversity. Changes in the way of the community also affect the process of implementing traditional rituals that last for hundreds of years and are hereditary.

\subsection{Suggestion}

Ethnography of communication research is very interesting to be done to reveal how rich Indonesia will be in local customs and culture which certainly has extraordinary local wisdom. There are still many opportunities for researchers to conduct ethnographic studies in the archipelago, such as equipment, the uniqueness or distinctiveness of ceremonies, rituals, and mantra 'spells'.

\section{References}

1. A. S. Ibrahim, Panduan Penelitian Etnografi Komunikasi (1994)

2. https//kbbi.kemdikbud.go.id

3. https://pakarkomunikasi.com/etnografi-komunikasi

4. Koentjaraningrat, Pengantar Ilmu Antropologi. (2002)

5. K. Zakiah, P.E.K.T.M, MT, 9 (2008)

6. H. Hadikusuma, Hukum Kekerabatan Adat (1987)

7. D. P. Prabowo, Pengaruh Islam dalam Karya-Karya R. Ng. Ranggawarsita (2003)

8. A. Isnaeni, K.M. Hakiki, S.I. A.P.A.L.P, K, 10, 193-222 (2016)

9. F. Sururi, M.D.J.S.p.M.A.L.P.M.P AH, 06, 124-145 (2016)

10. O. Katubi, L.L.L.f.N.E.o.T.P.o.L.S.i.L.a..T.Q.o.I.R. Tenth International Conference on Austronesian Linguistics, Puerto Princesa, Philippines (2006)

11. J.B. Kington, M.T.T.S.A.P.P.a.C.C.i.C.L. Ph.D. diss, Columbia University (1987)

12. D. Mulyana, Metodologi Penelitian Kualitatif: Paradigma Baru Ilmu Komunikasi dan Ilmu Sosial Lainnya. (2013)

13. C. Hanawalt, B.o.S.T.V.R.o.S.S.i.L.D (no publication year) 